Acta Technologica Agriculturae 2

Nitra, Slovaca Universitas Agriculturae Nitriae, 2016, pp. 49-51

\title{
NOISE EMISSIONS IN MILKING PARLOURS WITH VARIOUS CONSTRUCTION SOLUTIONS
}

\author{
Marie ŠíSTKOVÁ*1, Martin PŠENKA², Ivo CELJAK', Petr BARTOŠ', Štefan MIHINA ${ }^{2,3}$, Ivan PAVLÍK ${ }^{3}$ \\ ${ }^{1}$ University of South Bohemia in České Budějovice, Czech Republic \\ ${ }^{2}$ Slovak University of Agriculture in Nitra, Slovak Republic \\ ${ }^{3}$ National Agricultural and Food Centre, Animal Production Research Centre Nitra, Slovak Republic
}

\begin{abstract}
Mechanical devices in parlours are a source of noise, and this noise has an effect not only on the operators of the parlour but also on dairy cows. They have more sensitive hearing than humans. The aim of this article was to analyse the sound pressure level and determine the noise exposure of dairy cows at different technological solutions of milking parlours, during their day routine. In the experiment, tandem, herringbone and rotary milking parlours were used. Noise exposure was measured during the milking process. After evaluation of noise pressure levels of different types of milking parlours, it can be concluded that in this experiment, the equivalent noise pressure level was lowest in the tandem milking parlour. Equivalent sound pressure levels in the rotary and herringbone milking parlour were almost about the same values. These values are higher than values in the tandem milking parlour, about 10 decibels. The differences within mean $L_{\text {AFeq }}$ values between the herringbone milking parlour and tandem milking parlour were highly statistically significant $\left(P<0.001^{* * *}\right)$.
\end{abstract}

Keywords: dairy cows; milk producing; livestock housing

Nowadays, protecting the environment and reducing harmful substances becomes a high priority. Environmental protection must be part of person's life in the twenty-first century (Gálik et al., 2014). Noise emissions can also be regarded as harmful substances.

Animals have often more sensitive hearing than humans. They have different frequency spectra of sound perception with the maxima of frequencies that are inaudible to humans (Voipio, 1997). Some animals can well perceive sounds below and also above the frequencies in the audible range of an average human, i.e. from $20 \mathrm{~Hz}$ to $20 \mathrm{kHz}$. Cattle have audible range in the frequencies from $25 \mathrm{~Hz}$ to $35 \mathrm{kHz}$ and can capture lower lying sounds than other farmed animals (Heffner and Heffner, 1993).

Cattle housed in farm buildings are exposed to noise, which can come either from outside or from inside of the building (Castelhano-Carlos and Baumans, 2009).

Anthropogenic noise from ordinary human activities can have a negative impact on the welfare of cattle (Brouček, 2014).

Noise sources on farms can be, in addition to ordinary activities (opening and closing doors, washing, talking of employees, dispensing feed, etc.), also machinery, basal levels of noise caused by mechanical ventilation, animal activity (climbing to barriers, chewing on barriers) and their own vocalization (Žitňák et al., 2011; Mihina et al., 2012). Other sources of noise can also be mechanization used on farms, because of the noise either of the engine or hydraulic systems (Janoško et al., 2010).

Algers et al. (1978) detected noise levels in milking parlours and state values from $75 \mathrm{~dB}$ to $90 \mathrm{~dB}$. According to
Kauke (2007), noise intensity in most cases is unacceptable for dairy cows and also for operator (milker).

The limiting of excessive noise is a factor for improving the welfare and together with other criteria (parameters of air, lighting) creates a file generally known as microclimate (Kic and Brož, 1995; Webster, 1999).

\section{Material and methods}

\section{Research place}

The experiment was conducted on three farms for cattle in the Czech Republic.

Measurements were performed on a farm with 128 production dairy cows, with the tandem milking parlour BAUER TECHNICS $2 \times 4$ (year of manufacture 2012), with an automatic system ATA 25, placed outside next to barn. Dairy cows were milked two times per day. Cows moved to the parlour in groups of about 40 heads. Another group of cows is coming to the collection room after the last cow from the first group finishes milking.

The second measurements were performed in the farm with 536 production dairy cows, with the herringbone milking parlour Fullwood $2 \times 12$ Rapid Exit (year of manufacture 2009). Dairy cows were milked two times per day. Cows moved to the parlour in groups.

The third measurements were performed in the farm with 840 production dairy cows, with the rotary milking parlour ROTO 36 Fullwood (year of manufacture 2007) with 36 parlour places. Dairy cows were milked two times per day and they moved to the parlour individually. The numbers 


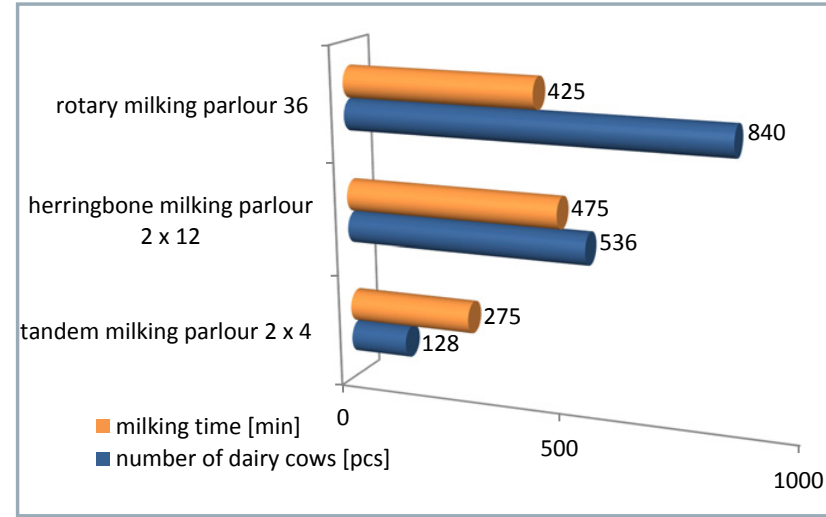

Figure 1 Graph of milking time and the number of dairy cows on each farm

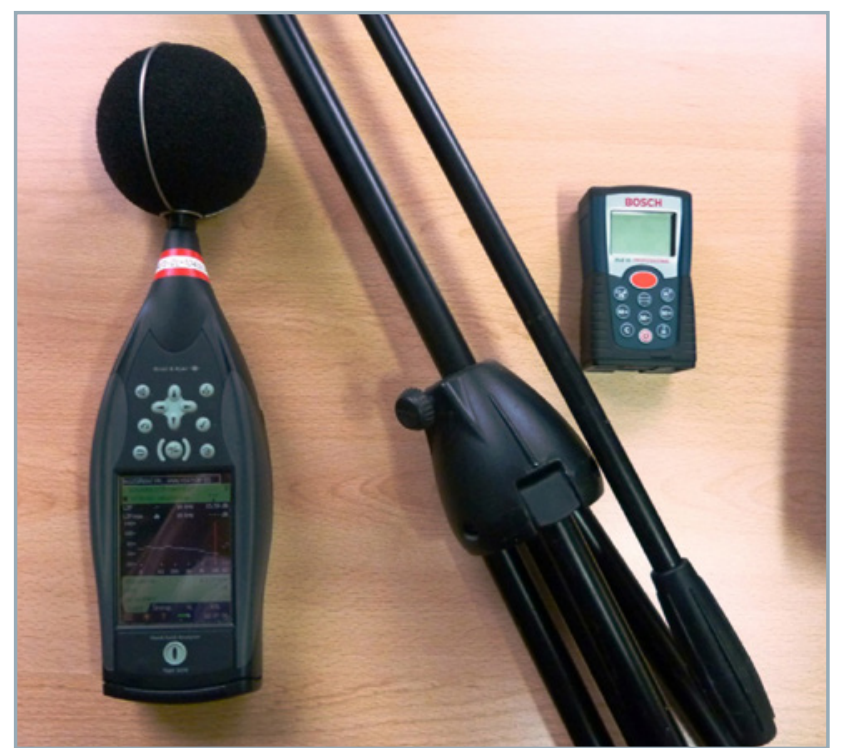

Figure 2 From the left to the right: Measuring device Brüel \& Kjær type 2270 with a tripod and digital distance meter Bosch DLE 50

of production dairy cows and milking process durations for each farm are shown in Figure 1.

\section{Measuring device}

A sound level meter Brüel\&Kjær of type 2270 was used for measuring of noise. It allows measuring sound levels in a standard way and carrying out the evaluation of the living and working environment. It consists of a microphone, preamplifier, processor and reading unit. The software allows measuring parameters in time and evaluating data statistically.

An electroacoustic sound calibrator AC - 300 was used for calibration before measurement.
Conditions during measurement were recorded by a digital meteorological station WS -1600 with an accuracy of $\pm 1{ }^{\circ} \mathrm{C} ; \pm 5 \%$, and the height of the microphone on a tripod was measured by a digital distance meter Bosch DLE 50 with accuracy class 2.

A software package SAS version 9.2 (SAS, 2009) was used to carry out given statistical procedures.

\section{Data acquisition}

Noise measurements were carried out directly in the parlour space, i.e. in the space where the cows were standing during milking. Measurements were performed during the milking process, i.e. when there was milking running.

There were made 15 repeated measurements in each parlour, the duration of the time interval of individual measurements was chosen to 180 seconds (to record any significant changes in noise levels in the parlour). The measuring device was placed at the level of animal heads. Before each series of measurements, calibration and control of measuring with the sound calibrator was carried out and the background noise level (when milking was off) was measured.

Equivalent sound pressure level $L_{\text {AFekv }}$ was recorded with the sound level meter, which reflects the equivalent value of sonic energy for a given measured period, weighted with the filter ' $A$ '. Another measured parameter was the maximum time-weighted sound level $L_{A F m a x}$.

\section{Results and discussion}

The measurements were conducted under the climatic conditions specified in Table 1.

Measured values of noise $L_{A F e q}(\mathrm{~dB})$ and $L_{\text {AFmax }}(\mathrm{dB})$ in parlours were processed in tables, and from these values, arithmetic averages were calculated and processed in the bar graph (Figure 3), where it is possible to see differences in exposure to noise, depending on the type of milking parlours.

As can be seen in Table 3, the differences within mean $L_{\text {AFeq }}$ values between the herringbone milking parlour and tandem milking parlour were highly statistically significant $\left(P<0.001^{* * *}\right)$. On the other hand, the differences within mean $L_{\text {AFmax }}$ values between all milking parlours to each other were not statistically significant.

As can be seen in Table 2 and Figure 3, the average maximum sound pressure levels were about the same, ranging from $82.0 \mathrm{~dB}$ to $84.2 \mathrm{~dB}$. This was due to the fact that during milking different noises are occurring, caused by metal parts hitting to each other. For example, metal barriers, namely chains, locking mechanisms of barriers, and so on. In reality, these values were in the range of $76 \mathrm{~dB}$ to $91 \mathrm{~dB}$.

In the rotary milking parlour, equivalent levels were in the range from $65.96 \mathrm{~dB}$ to $77.24 \mathrm{~dB}$, in the herringbone milking

Table 1 Climatic conditions during the measurement

\begin{tabular}{|l||c|c|c|}
\hline Location of measurement & Air temperature $\left({ }^{\circ} \mathbf{C}\right)$ & Relative humidity of air (\%) & Atmospheric pressure (hPa \\
\hline Rotary milking parlour & 19.1 & 64 & 943 \\
\hline Herringbone milking parlour & 20.1 & 54 & 991 \\
\hline Tandem milking parlour & 16.7 & 35 & 949 \\
\hline
\end{tabular}


Table 2 Sound pressure level values (values are given with standard deviation)

\begin{tabular}{|l||c|c|}
\hline & $\boldsymbol{L}_{\text {AFeq }}(\mathbf{d B})$ & $\boldsymbol{L}_{\text {AFmax }}(\mathbf{d B})$ \\
\hline Rotary milking parlour & $71.2 \pm 2.56$ & $83.4 \pm 4.27$ \\
\hline Herringbone milking parlour & $69.2 \pm 1.16$ & $82.0 \pm 2.87$ \\
\hline Tandem milking parlour & $60.8 \pm 1.24$ & $84.2 \pm 2.82$ \\
\hline
\end{tabular}

Table 3 Statistical significance of mean's differences (Student's T-test)

\begin{tabular}{|l||c|c|}
\hline Groups & P value $L_{\text {AFeq }}$ & P value $L_{\text {AFmax }}$ \\
\hline Herringbone - tandem & $\begin{array}{c}<.0001 \\
* * *\end{array}$ & 0.0571 \\
\hline Herringbone - rotary & $\begin{array}{c}0.0172 \\
*\end{array}$ & $\begin{array}{c}0.2167 \\
-\end{array}$ \\
\hline Tandem - rotary & $\begin{array}{c}0.0123 \\
*\end{array}$ & 0.1438 \\
\hline \multicolumn{2}{|c|}{$P<0.05^{*} ; P<0.01^{* *} ; P<0.001^{* * *}$} & - \\
\hline
\end{tabular}

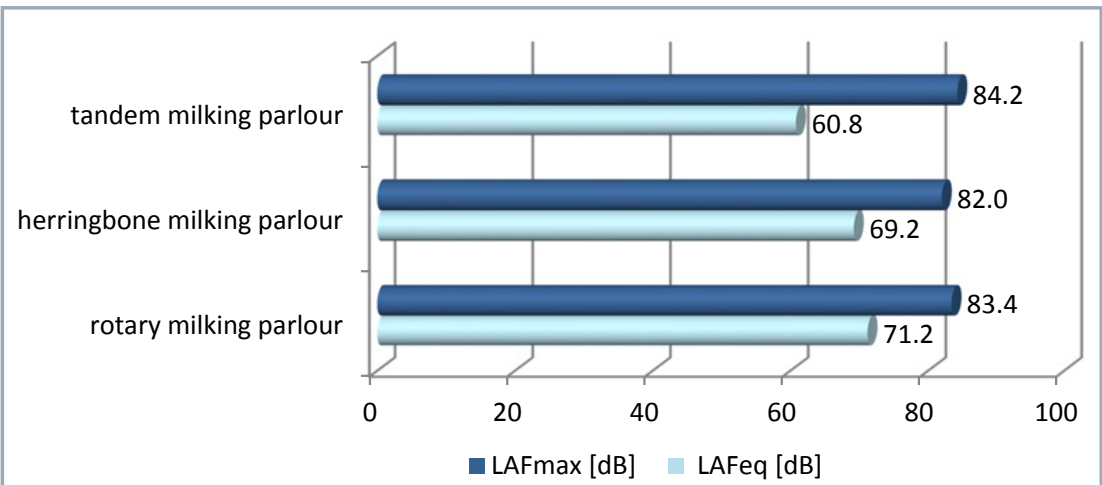

Figure 3 Noise emission values in parlours (values are given without measurement uncertainty)

parlour in the range from $67.2 \mathrm{~dB}$ to $70.53 \mathrm{~dB}$, and in the tandem milking parlour in the range from $59.68 \mathrm{~dB}$ to $64.86 \mathrm{~dB}$. Measured values as well as their arithmetic averages in Figure 3 indicate that while in the rotary milking parlour and in the herringbone milking parlour the values were almost the same - about $70 \mathrm{~dB}$, in the tandem milking parlour the levels were around $60 \mathrm{~dB}$.

Measured values and also their arithmetic means are pointing to the fact that in this experiment the tandem milking parlour was evaluated as less noisy, with an average equivalent sound pressure level $60.8 \mathrm{~dB}$. For comparison, the rotary milking parlour and herringbone milking parlour were exposed to higher equivalent sound pressure levels, 69.2 dB and 71.2 dB (Figure 3).

\section{Conclusion}

Dairy cows are the most noiseburdened category of cattle. In this experiment, sound pressure levels in milking parlours with different technological solution of milking were detected. Measured values were compared to determine the lowest level of noise stress among the examined farms. The noise which dairy cows in the parlour are exposed to does not need to come from technological devices and their usual activities. A very important factor is the way of performance of tasks during the milking process. Various short-lived and sudden noises, especially from metal parts have an impact on animal welfare. The lowest equivalent sound pressure level was found on the farm with the milking technology based on the tandem milking parlour.

\section{Acknowledgement}

This work was supported by the project KEGA no. 011SPU-4/2014 entitled 'Transfer of innovative technologies into the educational process in the dimensions of current needs of agriculture through university textbook' in cooperation with the BAT centre of the University of South Bohemia in České Budějovice.

\section{References}

ALGERS, B. - EKESBO, I. - STROMBERG, S. 1978. The impact of continuous noise on animal health. In Acta Veterinaria Scandinavica, 1978, Suppl. 67, pp. 1-26. BROUČEK, J. 2014. Effects of noise on performance, stress, and behavior of animals: A review. In Slovak Journal of Animal Science, vol. 47, 2014, no. 2, pp. 151-160.

CASTELHANO-CARLOS, M. J. - BAUMANS, V. 2009. The impact of light, noise, cage cleaning and in-house transport on welfare and stress of laboratory rats. In Laboratory Animals, vol. 43, 2009, pp. 311-327.

GÁLIK,R.-BOĎO, ̌̌.-MIHINA, Š.-STAROŇOVÁ, L. - MÁCHAL, P. - MAREČEK, J. - ZACH, M. 2014. The emission factors determination at different breeding technology of laying hens. In Acta Universitatis Agriculturae et Silviculturae Mendelianae Brunensis, vol. 62, 2014, no. 6, pp. 1265-1269.

HEFFNER, H. E. - HEFFNER, R. S. 1993. Auditory perception. In: Phillips, C. J. C. and Piggins, D. (ed.), Farm Animals and the Environment. Wallingford : $C A B$ International, 1993. pp. 159-184.

JANOŠKO, I.-ŠIMOR, R. -CHRASTINA J. 2010. The bio-oil testing used in the hydraulic system of the vehicle for waste collection. In Acta Technologica Agriculturae, vol. 4, 2010, no. 4, pp. 103-108.

KAUKE, M. 2007. Messungen von Larm, Vibrationen und Kriechstrom. In: Tanikoner Melketechniktagung. Melktechnologie der Zukunft; Das Zusammenwirken von Industrie, Beratung und Forschung. Ettenhausen : Forschungsanstalt Agroscope Reckenholz - Tanikon ART, pp. 29-34. ISBN 978-3-905733-04-4.

KIC, P. - BROŽ, V. 1995. Tvorba stájového prostředí. Praha : Institut výchovy a vzdělávání Ministerstva zemědělství České Republiky, 47 pp.

MIHINA, Š. - KAŽIMÍROVÁ, V. - COPLAND, T. A. 2012. Technology for farm animal husbandry. $1^{\text {st }}$ issue. Nitra : SUA, 99 pp. ISBN 978-80-552-0934-0.

SAS 2009. User's Guide Version 9.2. SAS/ STAT $^{\circledR}$ SAS Institute Inc. Cary, NC, USA.

VOIPIO, H. M. 1997. How do rats react to sounds? In Scandinavian Journal of Laboratory Animal Science, vol. 24, 1997, no. 1, pp. 1-80.

WEBSTER, J. 1999. Welfare: životní pohoda zvírat. Praha : Nadace pro ochranu zviŕat, 1999. 264 pp.

ŽITŇÁK, M. - LENDELOVÁ, J. - BUREŠ, L'. 2011. Working environment of dairymen in summer time. In Rural Buildings in European Regions: Architecture - Constructions Technology - Safety. (Proceedings of peerreviewed scientific works). Nitra: SUA, 2011. pp. 165-172. ISBN 978-80-552-0644-8. 